\title{
Making Model of Village Regulation based on Good Village Governance in Indonesia
}

\author{
Suparto Wijoyo \\ Magister of Science of Law and Development \\ Postgraduate School, Universitas Airlangga \\ Surabaya, Indonesia \\ suparto.wijoyo@fh.unair.ac.id
}

\author{
Radian Salman \\ Constitutional Law Department \\ Faculty of Law, Universitas Airlangga \\ Surabaya, Indonesia \\ radian@fh.unair.ac.id \\ Bagus Oktafian Abrianto \\ Administrative Law Department \\ Faculty of Law, Universitas Airlangga \\ Surabaya, Indonesia \\ bagusoa@fh.unair.ac.id
}

Abstract - In Article 1, Sub-Article 7, Act Number 62014 on Villages, it said that the Village Regulation is a regulation stipulated by the Urban Village Head after being discussed and agreed with the Village Consultative Body. The determination of the Village Regulation is an elaboration of the various authorities which are owned by the Village which refers to the provisions of the higher legislation. As a legal product, Village Regulation should not conflict with the higher regulations and should not harm the public interest, or the general interest as mentioned in Act Number 62014 on Villages which are: a. the disruption of communal harmony; $b$. the disruption of access to public services; c. the disruption of public order and tranquillity; $d$. the disruption of economic activities to improve the welfare of village communities; and e. the discrimination against tribe, religion, belief, race, intergroup, and gender. Village Regulations govern the village authority based on the right of origin and village local-scale authority. The implementation is supervised by the village communities and Village Consultative Body. It is intended to make the implementation of the Village Regulation always monitored continuously by local villagers because village regulations are set for the benefit of the village community as a whole. The provisions on the right of origin are explained as "the right of origin" which is a living legacy and the initiative of the village or the initiative of the village's society in accordance with the development of community life, including indigenous peoples' organisational systems, institutions, customary law, the ground of the village's treasury, and agreements in village life as well. The meaning of "village-scale local authority" is the authority to regulate and manage the interests of the village community that has is conducted by the village, is able and effective when conducted by the village or what has arisen because of the development of the village and the village community, such as boat moorings, the village market, public baths, irrigation canals, environmental sanitation, preand postnatal health care and information, art and learning centres, and village libraries, village retention basins, and village roads. In the context of good village governance, the village regulations should reflect: 1) Participation; 2) Law enforcement (rule of law); 3) Transparency; 4) Responsive; 5) Consensus orientation; 6) Equity; 6) Effectiveness and efficiency and 7) Accountability and strategic vision. The ways and mechanisms for the formulation of village regulations that reflect the principles of good village governance will be explained further in this study, in the pre-establishment stage, establishment stage, and post-establishment stage of village regulations.

Keywords-right of origin and village-scale local authority; village regulation; good village governance; village society; village consultative body

\section{INTRODUCTION}

The "good governance" principle gives the paradigm change of government relations to the public. Nowadays, the government acts as a public servant, so the reason why the good governance principle is needed in government system, especially related to public service, is namely because 1) the improvement of public services is important for the stakeholders which are the government, citizens and market participants. The government is concerned with legitimacy, because the better the service, the smaller the bureaucracy cost in improving the welfare of citizens and the efficiency of the market mechanism; 2) Public service is the sphere of the three elements of governance in conducting intensive interactions. Through the provision of public services, the government, citizens and market participants interact intensively so that if the government can improve the quality of public services, the benefits can be felt directly by the communities and market participants. This is important for the stakeholders to believe that the government has seriously changed. The existence of trust is a very important prerequisite to support good governance practice and 3) Values that characterise good 
governance practices can be interpreted through public services. The executor of the activity can develop an efficient, fair, transparent, accountable and participative public service system and the success of carrying out such activities will transmit into other spheres so that good governance can gradually be institutionalised in every government activity. ${ }^{1}$

The lowest government level is the village. The village is community entity which was born before Indonesia as it is today was formed. Historically, the village is the pioneer of the political community and government in Indonesia. Social structures like the village, custom community and others have become social institutions which have an important position. The village is a highly autonomous institution with its own traditions, customs and laws and it is relatively independent. This is indicated by the high level of diversity, making the village the most concrete form of the nation. ${ }^{2}$ According to Philipus M. Hadjon, long before the colonial period in all corners of the country, there have been native government units, either the kingdoms or the lower ones, i.e. villages or clans, kuria, towns, villages, nagari, negorij and so on. Indigenous governments are called villages (Java). Those outside Java are called dusun, marga, nagari, negorij, city, kuria, and so forth; they are a form of native democratic government. Similar to self-governance, the village government is organised and conducted according to Customary Law. ${ }^{3}$

According to the purpose of the country, which is in fourth paragraph in the Opening of UUD 1945, it mentions that one of the purposes of the country is to advance the public's welfare. The village is a country entity which is in the front row of the efforts of conducting the purpose of the country. This is because the village is the lowest structure which is close to the public and directly connected to the public when conducting public services. The village instrument used to realise the welfare of the community is the village regulations. So in the system of the formation of village regulations, one must pay attention to the principles of good governance for the public services implemented by the village government to run optimally. This research study will explain the mechanism of the establishment of village regulations in accordance with the principles of good governance in order to implement the state goal of public welfare. The research method used was normative legal research with the approach of theory and legislation. The purpose of this study is to obtain a comprehensive picture of the formation of village regulations in accordance with the principles of good village governance.

\section{The NATURe of Village RULES IN The Constitutional SYSTEM}

\footnotetext{
1 Agus Dwiyanto, 2008, Mewujudkan Good Governance Melalui Pelayanan Publik, Yogyakarta: Gadjah Mada University Press, p. 4-5.

${ }^{2}$ HAW. Widjaja, OTONOMI DESA Merupakan Otonomi yang Asli, Bulat, dan Utuh, RajaGrafindo Persada, Jakarta, 2004, p. 4

${ }^{3}$ Philipus M.Hadjon, et al, Pengantar Hukum Administrasi Indonesia, Gadjah Mada University Press, Yogyakarta, 2002, p. 111
}

The term village comes from the word "swadesi" (sansakerta language) which means an independent, autonomous region, place or part. It is also introduced by Sutardjo Kartohadikoesoemo with the words "desa", "dusun", "desi" (remember the words swadesi) which are similar to negari, nagari, negory, which mean homeland. In Japanese, the village is called "mura" and the rules made by the village government are called "hokimura". ${ }^{4}$ Law 6/2014 divides the village into two kinds, namely village and custom village. The village carries out its administration in accordance with the provisions laid out in village law. Meanwhile, custom villages exercise their authority in various areas of village governance based on the rights of origin and customs that live in the community. The determination of a village as a custom village is determined by provincial regulations. Villages, both villages based on customary village and village laws, constitute a legal community unity that has territorial borders authorised to regulate and administer government affairs, the interests of local communities based on community initiatives, origins rights, and / or recognised traditional rights in the system of government of the Unitary State of the Republic of Indonesia.

Indroharto explained that authority can be obtained through the original source of attribution, delegation, and mandate authority. Attribution is the granting of authority of the new government by a provision in the legislation. A delegate is an assignment of an existing authority by the TUN or TAK Agency which has obtained an attributive governmental authority to another TUN or TAK. Thus, a delegation is always preceded by an attribution of authority. In the mandate, there is no new authorisation or delegation of authority from the TUN or the TUN to the other. ${ }^{5}$

Article 18 Paragraph (1) of the 1945 Constitution of the Republic of Indonesia states that the Unitary State of the Republic of Indonesia is divided into provinces. Provinces are divided into districts and municipalities. Each province, regency and city has a local government, which is regulated in Law. Besides that, local governments have the authority to adopt regional or other regulations in the context of the implementation of autonomy and assistance tasks. The enactment of Law No. 23/2014 and Law No. 4/2014 has consequences for the position of village government in the state administration system in Indonesia. Law 23/2014 regulates villages in Chapters XVIII articles 371 to 372 . Article 371 paragraph (1) and (2) of Law 23/2014 states that in regencies / municipalities, villages and villages can be established in accordance with the provision of laws and regulations with the Law of Village. Based on Article 372 paragraph (1) of Law 23/2014, it states that the Central Government, Provincial Government and Regency / Municipal Government can assign parts of Government Affairs to the Village. Based on the above, the authority of the village comes from the delegation of authority. The delegation may come

\footnotetext{
${ }^{4}$ Ateng Syafrudin dan Suprin Na'a, Republik Desa-Pergulatan Hukum Tradisional dan Hukum Modern Dalam Desain Otonomi Desa, Bandung: Alumni, 2010, p. 2 and p. 18

${ }^{5}$ Indroharto, Usaha Memahami Undang-undang tentang Peradilan Tata Usaha Negara, Jakarta: Pustaka Harapan, 1993, h. 68
} 
from the central government, provincial government, or district / city government.

Article 18 of Law 6/2014 explains that the Village Authority covers authority in the field of Village Governance, Village Development, Village Community Development, and Village Community Empowerment based on community initiatives, village rights and village customs. Article 19 of Law 6/2014 explains that the authority of the village includes a) the authority based on the right of origin; b) the local authority at village level; c) the authority assigned by the Government, Provincial Government, or Regency / City Government and d) other authorities assigned by the Government, Provincial Government, or Regency / City Government in accordance with the provisions of the laws and regulations. When connected with the purpose of the state as referred to in the 4th paragraph of the 1945 Constitution of the Republic of Indonesia, the provisions of Article 18 of the 1945 Constitution of the State of the Republic of Indonesia, articles 371 and 372 of Law 23/2014 and articles 18 and 19 of Law $6 / 2014$ can be explained that in order to realise the aim of the state is to promote the general welfare, the authority of the government is divided vertically in to regions. The village as a manifestation of the unity of the legal community has certain authority. One of the authorities of the village comes from the delegation of authority from the central government, provincial government, or district / city government.

The implementation of the village authority is carried out through the existing regulatory instruments in the village, i.e. village regulations, Head of the Village and Head of the Village regulations. Establishing a new legislation must be in accordance with good planning, in order to determine that the clarity of the purpose of the legislation is formed. Planning for the establishment of legislation is strongly influenced by the concepts and mechanisms of the regulation. With the concept and mechanism of the formation of good rules, the rules will be in accordance with the applicable legal principles. Taking into account the above provisions, it can be concluded that the understanding of the village is technically and legislative, making the village the lowest government level that can exercise the power of its own government based on the right of its origin in achieving the welfare of its people as an autonomous region. ${ }^{6}$

According to Article 7 and 8 of Law 12/2011, it states that the type and hierarchy of legislation consists of: a. 1945 Constitution of the State of the Republic of Indonesia; $b$. Decision of the People's Consultative Assembly; c. Law / Government Regulation in Lieu of Law; d. Government regulations; e. Presidential decree; f. Provincial Regulations and g. Regency / City Regulations. The legal power of legislation is in accordance with the hierarchy. The types of legislation other than those referred to in Article 7 paragraph (1) include regulations established by the People's Consultative Assembly, the People's Legislative Assembly, the Regional Representative Council, the Supreme Court, the Constitutional Court, the Supreme Audit Board, the Judicial

${ }^{6}$ Setyo Nugroho, Demokrasi dan Tata Pemerintahan dalam Konsep Desa dan Kelurahan, Jurnal Cita Hukum Vol. I No. 2 Desember 2013, p. 256
Commission, Bank Indonesia, a commission, body or a commission of the same level established by law or the government on the order of the Act, Provincial People's Legislative Assembly, Governor, Regency / Municipal House of Representatives, Regent / Mayor, Head of the Village or equivalent.

The village regulation is a legislation established by the Head of the Village after being discussed and agreed by the Village Consultative Board. Village Rules are containing material for the exercising of the village authority and for the further elaboration of the higher Legislation Regulations. The content of the implementation of village authority includes a) the Village Revenue and Expenditure Budget of deliberation between the Head of the Village and the village consultative body; b) Medium-Term Development Plan of Village and Work Plan of Village Government and c) the establishment of Village-Owned Enterprises agreed through Village Deliberations. In other words, it can be explained that the village arrangement is part of the legislation established by way of deliberations between the Head of the Village and the village consultative body which contains provisions concerning the Budget of the Village, the Medium Term Development Plan for The Village, Village Government Meeting, and Village-Owned Enterprises.

\section{THE PROCEDURE OF VILLAGE REGULATION FORMATION}

The procedures for establishing village regulations should be in accordance with the procedures for the establishment of legislation because village regulations are a part of the legislation. The formation of the legislation is the drafting of the rule of law. Or in other words, the formulation of legislation is a way of drafting the draft regulations according to the demands, theories, principles, and rules of legislative drafting. The formulation of legislation should really pay attention to the principles of the establishment of good legislation, including: 1 . The clarity of the purpose. 2 . the right organising or organising body. 3. The conformity between the type and material of charge. 4. It can be implemented. 5 . utility and usability 6 . the clarity of formulation and 7 . openness.

The stages of the establishment of village regulations in accordance with the provisions of the Minister of Home Affairs 111/2014 include a) Planning; b) Preparation; c) Discussion; d) Determination; e) promulgation; f) dissemination and g) evaluation and clarification. The planning of the drafting of the Village Decree is determined by the Head of the Village and BPD in the Village Government work plan. Civic institutions, customary institutions and other village institutions in the village can provide input to the Village Government and / or BPD for the drafting plan of the Village Regulations.

The drafting of Village Rules was initiated by the Village Government. The draft Village Rules should be consulted with the village community and can be consulted to the sub-district head to get further input. The villagers who are consulted are 
communities or community groups that are directly related to the substance of the regulatory material. Input from the village communities and sub-district heads is used by the Village Government to follow up the drafting process of the Village Rules. The draft Village Regulation, which has been consulted on, is submitted by the Head of the Village to the BPD to be discussed and mutually agreed upon.

At the drafting stage, the BPD may draft and propose a draft Village Rule except for the draft Village Regulations on the village mid-term development plan, the draft Village Regulations on the Village Government's work plan, the draft Village Regulation on Village Budgets and the draft Village Regulation on accountability reports for the realisation of APB. The draft of the village regulations that can be drafted and proposed by the BPD can be proposed by the members of the BPD to the head of the BPD, to be designated as the draft village regulation of the proposed BPD.

At the discussion stage, the BPD invites the Head of the Village to discuss and agree on the draft Village Rules. In the case of a Village Rural Village Initiative draft and a BPD proposal on the same matter to be discussed within the same discussion time, priority is given to the draft Village Rules proposed by BPD while the Village Rule Design proposal of the Head of the Village is used as the material to be compared. The draft Village Regulation that has not been discussed can be withdrawn by the proposer. The draft Village Rules which have been discussed cannot be withdrawn except by mutual agreement between the Village Government and the BPD. The agreed Village Rules draft shall be submitted by the head of the Village Consultative Body to the Head of the Village to be determined to be a Village rule no later than 7 days from the date of the initial agreement. The draft of the village regulations shall then be stipulated by the Head of the Village by signing no later than 15 days from the receipt of the village regulation draft from the leadership of the Village Consultative Body.

At the stipulation stage, the draft Village Regulation which has been signed by the Head of the Village shall be submitted to the Village Secretary to be enacted. In the event that the Head of the Village does not sign the Village Rules Draft, the Village Rule Draft shall be promulgated in the Village Gazette and shall therefore be valid as Village Rules. At the enactment stage, the Village Secretary enacts village regulations in village sheets. Village regulations are then declared to come into force and have binding legal force since their enactment.

The dissemination stage, which is dissemination conducted by the Village Government and BPD since the establishment of the draft of the Village Rule plan, the compilation of the Village Unity Plan and the discussion of the Village Rule Design through to the Enactment of the Village Regulation. Dissemination is conducted to provide information and to obtain input from the community and stakeholders.

In the evaluation phase, the Village Rule Design on Village APB, Spatial Levy and Village Government Organisations has been discussed and agreed on by the Head of the Village and
BPD, submitted by the Head of the Village to the Regent / Mayor through the Sub-district Head or other designations no later than 3 days since it was agreed to be evaluated. In the event that the Regent / Mayor does not provide an evaluation result within the time limit, the Village Rule applies by itself. The evaluation results of the draft of the Village Regulations shall be submitted by the Regent / Mayor no later than 20 working days as from the receipt of the draft Regulation by the Regent / Mayor. In the event that the Bupati / Walikota has given the evaluation result, then the Head of the Village is obliged to improve it. The Head of the Village will fix the draft no later than 20 days after receipt of the evaluation result. The Head of the Village may invite the BPD to improve the village regulation draft. The results of the correction and follow-up are submitted by the Head of the Village to the Regent / Mayor through the Sub-District Head. In the event that the Head of the Village does not follow up on the evaluation results, and still stipulates the Village Regulations, the Regent / Mayor cancels the Village Regulation by the Decree of the Regent / Mayor. The Regent / Mayor may form an evaluation team for the Village Rule Design. The team is determined by the decision of the Regent / Mayor.

At the clarification stage, the Village Regulation that has been enacted is submitted by the Head of the Village to the Regent / Mayor no later than 7 days since the enactment has to be clarified. The Regent / Mayor clarifies the Village Regulation by establishing a clarification team no later than 30 days after it is received. The results of clarification as referred to in Article 19 paragraph (1) may be: a. Results of clarification that are in accordance with the public interest, and / or the provisions of the higher Legislation and b. Results of clarification that are contrary to the general interest and / or the provisions of the higher Legislation. (2) In the event that the result of clarification as referred to in paragraph (1) of the Village Regulation is not contradictory to the public interest, and / or the provisions of the higher legislation, then the Regent / Mayor shall issue a clarification letter containing the appropriate clarification result. (3) In the event that the result of clarification as referred to in paragraph (1) is contradictory to the public interest, and / or the provisions of the higher legislation, then the Regent / Mayor cancels the Village Regulation by the Decision of the Regent / Mayor.

\section{FORMATION OF VILLAGE REGULATION BASED ON GOOD VILLAGE GOVERNANCE PRINCIPLES}

Good Governance was originally used in the corporate world and in the urgency to formulate a concept to do with creating inherent control of the corporation and its professional management, Good Corporate Governance was established. It is known that the main principles in Corporate Governance are transparency, accountability, fairness, responsibilitas, and responsiveness. ${ }^{7}$ The establishment of the legislation aims to establish good legislation. A. Hamid S. Attamimi divided the principles in the formulation of

${ }^{7}$ Nugroho D Riant, 2004, Kebijan Publik, Formulasi Implementasi dan Evaluasi, Jakarta.Gramedia, h. 216 
legislation into 2 classifications, namely the formal principles and material principles. Formal principles include the principle of clear purpose or beginsel van duideleijke doelstelling; The right organ / institutional principle or beginsel van het juiste orgaan; The principle of the necessity of setting or het noodzakelijkheids beginsel; The principle may be exercised or het beginsel van uitvoerbaarheid and the principle of consensus or het beginsel van consensus. The material principles include the principle of the terminology and systematic correctness or het beginsel van duidelijke terminology en duidelijke systematiek; The principle of being recognisable or het beginsel van de kenbaarheid; The principle of equal treatment in law or het rechtsgelijkheidsbeginsel; The principle of legal certainty or het rechtszekerheids beginsel; There is also the principle of law enforcement according to individual circumstances or het beginsel van de individualuele rechtbedeling.

The concept of global administrative governance through the implementation of good governance is an issue that has been initiated by the UNDP (United Nation Development Program) and World Bank since 1997 as a condition of fund disbursement to solve the problem of monetary crisis in Indonesia. This is intended to facilitate public bureaucracy in government and indirectly as an effort to facilitate access to free trade through simple bureaucratisation. ${ }^{8}$ The UNDP (United Nations Development Program) argues that the characteristics of the principles that should be embraced and developed in good governance practices include 1. Participation. Every person or citizen has a voting right in the decision-making process, either directly, or by way of representative institutions in accordance with their respective interests and aspirations. 2. Rule of Law. The legal and regulatory framework should be fair, enforced and adhered to in full, especially the rule of law on Human Rights. 3. Transparency. Transparency must be built in the framework of freedom of information flow. 4. Responsiveness. Each institution and process must be directed towards efforts to serve the various stakeholders 5. Good governance will act as a mediator for the different interests to reach a consensus or opportunity which is best for the interests of each party and if it is possible, to also apply this to various policies and procedures to be established by the government. 6. Equity. Good governance will provide the best opportunity for legal subjects in their efforts to improve and maintain the quality of life. 7. Effectiveness and Efficiency. Every process of an activity and institutions is directed to produce something that suits their needs through the best utilisation of the various resources available. 8. Accountability. Decision makers in private and public sector organisations have accountability to the public as well as to their stakeholders ${ }^{9} .9$. Strategic vision. Leaders and communities have a perspective to do with the broad and long-term aspects of good governance and human development, together with the perceived need for development. ${ }^{9}$

\footnotetext{
${ }^{8}$ Tedi Sudrajat, "Perwujudan Good Governance melalui format reformasi Birokrasi Publik dalam Perspektif Hukum Administrasi Negara", Jurnal Dinamika HukumVol. 9 No. 2 Mei 2009, h. 120.

${ }^{9}$ Soedarmayanti, 2003, Good Governance (Kepemerintahan Yang Baik) Dalam Rangka Otonomi Daerah, Bandung:Mandar Maju, h. 5-6
}

Good Governance is a form of development management, called development administration. The government becomes the agent of change in society (developing) in a developing country. The agent of change, because of the desired changes and planned changes, is also called the agent of development. Drivers of the development process include changes in the nation's society. The governments push through policies and programs, projects, even industries, and important planning and budgeting roles. Planning and budgeting also stimulates private sector investment. Policies and the approval of investment is in the hands of the government. ${ }^{10}$ The State Administration (LAN) defines good governance as the process of organising state power in implementing the provision of public goods and services. Furthermore, LAN affirms that in terms of the functional aspect, governance can be seen from whether or not the government has functioned effectively and efficiently in an effort to achieve the objectives outlined otherwise. ${ }^{11}$ Thus, good village governance is the implementation of good governance in the village. Based on the above understanding, good village governance is the principle of good governance in the village administration.

Law 322009 on Environmental Protection and Management stated in Article 1 paragraph (3) states that indigenous and tribal peoples are a group of people who have traditionally settled in certain geographical areas because of the ties to their ancestral origins. They have a strong relationship with the local environment and have a value system that determines economic, political, social, and legal order. The Balinese indigenous peoples are a society that is based on a combination of principles of singularity, and the similarity of localities, religion and interests, both in the mortal world and in the afterlife. ${ }^{12}$

Local wisdom is a cultural knowledge that belongs to a particular community group that includes models of sustainable natural resource management, including how to maintain relationships with nature through wise and responsible utilisation. ${ }^{13}$ Local wisdom becomes a system that integrates knowledge, culture, institutions, and the practice of managing natural resources with a vision of conservation which is one of the important aspects of local wisdom related to natural resource management. Thus, local wisdom is an integral part of the sociocultural identity of community groups that is closely related to ethnic identity. Laksono stated that wisdom is not a fixed price that can condition the history of the people concerned. Wisdom is a historical product of the local community in order to adapt to its environment. The wisdom contained in the sections that have implications is transcendental because it involves a matter of life and death

$$
10
$$$$
\text { Accessed }
$$
from

http://www.kemendagri.go.id/article/2014/06/12/perkembangan-paradigmagood-governance July, $17^{\text {th }} 2017$ at $10.00 \mathrm{pm}$

${ }^{11}$ Joko Widodo, Good Governance; Telaah Dari Dimensi Akuntabilitas, Kontrol Birokrasi Pada Era Desentralisasi Dan Otonomi Daerah, Surabaya: Insan Cendekia, 2001, h. 24

${ }^{12}$ Moch. Koesnoe, 1979, Catatan-Catatan terhadap Hukum Adat Dewasa Ini, Airlangga University Press, Surabaya, h. 18

${ }^{13}$ Hariadi Kartodihardjo dan Hira Jhamtani, Politik Lingkungan dan Kekuasaan di Indonesia, Equinox Publishing Indonesia, Jakarta, 2006, h. 
that was never resolved, but there is also a part of wisdom to do with precise and actual change according to the situation and conditions. ${ }^{14}$

Implementation can acknowledge the existence of local wisdom in PP 43/2014 on the Rules of Implementation of Law 6/2014 as amended by PP 47/2015 on the Amendment of PP 43/2014 About the Implementation of Law 6/2014. Article 19 of Law 6/2014 jo. Article 33 letter PP 43/2014 states that one of the authorities of the Village includes authority based on the right of origin. Article 34 Paragraph (1) of Government Regulation 47/2015 states that the Village Authority based on the right of origin as referred to in Article 33 letter A shall at least consist of: A. Systems of indigenous peoples' organisations; B. Community institutional development; C. Institutional development and customary law; D. Village cash management and E. Development of the roles in village communities.

Under this provision, it can be concluded that the government recognises the existence of the right of origin which, in this context, we align with an understanding of local wisdom. Under the provisions of article 2 of the Village Candy, Development of Disadvantaged Regions, and Transmigration 1/2015 Concerning the Authority Guidance Based on Origin and Village Scale Local Authorities, the scope of the authority based on the right of village origin shall include: a. Village organisation system; b. Systems of indigenous peoples' organisations; c. Community institutional development; d. Institutional development and customary law; e. Village cash management; f. Village land management or village ownership land using local designations; $g$. Management of crooked land; h. Management of pecatu land; i. Titisara ground management; and j. Development of roles of village communities. Governments, provincial and district / city governments must recognize, respect and protect authority based on the right of origin.

Based on the provisions as we have described above, it can be concluded that the state recognises and respects local wisdom. In this context, this is called the origin right with criteria determined by the legislation. The problem is what the form of recognition is and what instruments are used as parameters for the recognition and respect of the right of the origin. If there is a link between good village governance and local wisdom, then local wisdom is an integral part of the principle of good village governance, or in other words, it can be said that a good village governance style in Indonesia is in line with local wisdom. If the principle of good village governance is in conflict with local wisdom, then the local wisdom takes precedence. This is because the village is considered to have implemented good village governance if it has been based on wisely localised wisdom.

14 Laksono, P.M. 1995. "Kearifan tradisional dan Perlindungan Lingkungan di Indonesia". Journal Analisis CSIS: Budaya, Kearifan Tradisional dan Pelestarian Lingkungan. XXIV. No. 8, 1995 dikutip oleh M.P Karidewi, Su Ritohardoyo dan L.W. Santosa, Desa Adat Tenganan Pegringsingan Dalam Pengelolaan Hutan Di Desa Tenganan, Kecamatan Manggis, Karangasem, Bali, Majalah Geografi Indonesia Vol 26 No. 1 Maret 2012, h. 30

\section{VILLAGE REGULATION AS THE INSTRUMENT OF CLIMATE CHANGE CONTROL}

The regulations on the linkage between village and climate change is found in the LH 19/2012 Regarding Climate Village Program and the Regulation of the Director General of Climate Change Control P.1 // PPI / SET / KUM.1 / 2/2012 in the Guidelines for the Implementation of the Climate Kampung Program (PROKLIM). The Climate Village Program is a national scheme run by the Ministry of Environment and Forestry in order to increase the involvement of communities and other stakeholders to strengthen their adaptive capacity on climate change impacts, to reduce greenhouse gas emissions and to provide recognition of climate change adaptation and mitigation measures that have been done that can improve welfare at the local level in accordance with the conditions of the region. The Climate Village is the location that is in the lowest administrative area at the level of the neighbourhood or hamlet and the highest level of village or village are areas where people have made efforts to adapt and mitigate climate change on an ongoing basis.

The objective of the climate kampung program is to increase the understanding of climate change and its impacts, and to encourage real action implementations that strengthen community resilience in the face of climate change and contributing to GHG emission reduction efforts. The Special Purposes of the Climate Village Program are: a. Encourage community groups to adapt to and mitigate climate change at the local level. b. Provide recognition of adaptation and climate change mitigation actions at the local level that community groups have undertaken. c. Providing recognition to local governments in strengthening the implementation of PROKLIM. d. Giving recognition to supporters in order to facilitate the formation and development of PROKLIM. e. Encouraging the dissemination of climate change adaptation and mitigation activities that have been successfully implemented at a certain location to be applicable in other areas according to local conditions and the needs of local communities.

Based on the above description and analysis, the provisions of Law 23/2014 jo. Law 6/2014 should provide legitimacy to local wisdom. In addition, the Regulation of LH 19/2012 and the Regulation of the Director General of Climate Change Control P.1 // PPI / SET / KUM.1 / 2/2012 was on the grounds that it should include Law 6/2014 and Permendes, PDT and Transmigration $1 / 2015$ so that the climate village program can be connected to the provisions in the village. Other than that, related to Permendagri 111/2014, it should also include provisions concerning the content of the village regulations related to local wisdom in line with the climate kampung program as referred to in Article 21 Permendes, PDT and Transmigration 1/2015 which states that the Head of the Village should enact a Village Regulation on authority based on Right of Origin and local authority at the village scale. A climate village program which it is based on local wisdom or 
an authority based on village rights should be set forth in a legal instrument in the form of village regulations. The mechanism for establishing the village regulations should be based on the mechanism for the establishment of new legislation.

\section{CONCLUSION}

Village regulation is a legal instrument established by the Head of the Village after being discussed and agreed with the BPD containing materials for the exercising of village authority and further elaboration of the higher Legislation Regulations. The authority of the Village includes the authority in the field of Village Governance, the implementation of Village Development, Village Community Development, and Village Community Empowerment based on the community's initiative, the right of origin, and the village's customs. The authority based on customary village customary rights includes a. Structuring the organisational and institutional system of indigenous peoples; b. Customary law institutions; c. Ownership of traditional rights; d. Customary village cash management; e. Ulayat land management; $\mathrm{f}$. Agreement in indigenous village community life; g. Filling the position of customary Head of the Village and village customary apparatus and $h$. The tenure of the customary Head of the Village. Authority based on the right of origin should not be in conflict with the climate kampung program. The content of the village rules should be aligned with the climate kampung program in order to gain legitimacy. The rules should be established by village regulations by mapping the content material in line with the authority of the right of origin and local wisdom.

\section{References}

\section{Book}

Dwiyanto, Agus, Mewujudkan. Good Governance Melalui Pelayanan Publik, Yogyakarta: Gadjah Mada University Press, 2008.

Hadjon, Philipus M., et al, Pengantar Hukum Administrasi Indonesia, Gadjah Mada University Press, Yogyakarta, 2002.
Indroharto, Usaha Memahami Undang-undang tentang Peradilan Tata Usaha Negara, Jakarta: Pustaka Harapan, 1993.

Kartodihardjo, Hariadi dan Hira Jhamtani, Politik Lingkungan dan Kekuasaan di Indonesia, Equinox Publishing Indonesia, Jakarta, 2006.

Koesnoe, Moch., Catatan-Catatan terhadap Hukum Adat Dewasa Ini, Airlangga University Press, Surabaya, 1979.

Riant, Nugroho D, Kebijan Publik, Formulasi Implementasi dan Evaluasi, Jakarta: Gramedia, 2004

Soedarmayanti, Good Governance (Kepemerintahan Yang Baik) Dalam Rangka Otonomi Daerah, Bandung:Mandar Maju, 2003.

Syafrudin, Ateng dan Suprin Na'a, Republik Desa-Pergulatan Hukum Tradisional dan Hukum Modern Dalam Desain Otonomi Desa, cet. I, Bandung: Alumni, 2010

Widjaja, HAW, OTONOMI DESA Merupakan Otonomi yang Asli, Bulat, dan Utuh, RajaGrafindo Persada, Jakarta, 2004

Widodo, Joko, Good Governance; Telaah Dari Dimensi Akuntabilitas, Kontrol Birokrasi Pada Era Desentralisasi Dan Otonomi Daerah, Surabaya: Insan Cendekia, 2001

\section{Journal}

Karidewi, M.P, Su Ritohardoyo dan L.W. Santosa, Desa Adat Tenganan Pegringsingan Dalam Pengelolaan Hutan Di Desa Tenganan, Kecamatan Manggis, Karangasem, Bali, Majalah Geografi Indonesia Vol 26 No. 1 Maret 2012.

Setyo Nugroho, Demokrasi dan Tata Pemerintahan dalam Konsep Desa dan Kelurahan, Jurnal Cita Hukum Vol. I No. 2 Desember 2013

Tedi Sudrajat, "Perwujudan Good Governance melalui format reformasi Birokrasi Publik dalam Perspektif Hukum Administrasi Negara", Jurnal Dinamika HukumVol. 9 No. 2 Mei 2009

\section{Website}

http://www.kemendagri.go.id/article/2014/06/12/perkembanga n-paradigma-good-governance 